\title{
IDENTITY, REGIONAL ETHNICITY AND NATIONALITY IN CARTHAGINIAN DISCOURSE
}

\author{
EKA AVALIANI \\ International Black Sea University (Georgia) \\ eavaliani@ibsu.edu.ge
}

\begin{abstract}
This paper explores the sociopolitical and state dynamics of the Carthaginian statehood, early manifestations of nationhood and nationalism and also unpacks issues such as the identity and regional ethnicity in Carthaginian discourse. This study argues there were indeed ancient nations and that Carthage represents one of the best examples. Carthaginian citizens and allies exhibited their national affiliation in a variety of ways, most notably via a willingness to fight for the Carthaginian national collective in the face of extreme duress during the Punic Wars.
\end{abstract}

KEYWORDS: Carthaginian statehood, Regional Ethnicity, Nationality, Self-identification.

\section{Introduction.}

Theories, Reconstruction Methods and Methodological Approaches

The problems of better understanding nationality have, since the 1970s, been considerably explained. Much of that clarification has been a result of renewed attention given to the subject, even though expressed through numerous, sharply divergent analyses, for example in the works of Walker Connor, John A. Armstrong, Ernest Gellner, Benedict Anderson, Anthony D. Smith, Pierre L. van den Berghe, John Breuilly, Eric Hobsbawm, Liah Greenfeld, Dominique Schnapper and John Hutchinson. No one during this period has done more to clarify those problems than Anthony D. Smith, first by refining, through his 'ethno-symbolic' approach, the analysis of nationality in the context of enduring ethnicity (The Ethnic Origins of Nations 1986), territorial kinship (Nation and Ethnoscape 1997), and long-term cultural, political and symbolic development and coalescence of collectivities (The Antiquity of Nations 2004; The Nation in History 2000); and sec- 
ond, by examining the presuppositions of those divergent analyses (Nationalism and Modernism 1998). ${ }^{1}$

The study of nations and nationalism is often restricted to the examination of modern nations that appeared after the French Revolution. This is because the dominant trend in academic discourse argues that nations only came into existence as a result of modern technologies, mass printing and high levels of literacy. These features are deemed necessary because it has previously been assumed there was no way for individuals within earlier societies to imagine they were part of a larger nation of people similar to themselves. However, Nations are human communities with common cultural features, languages, myths, ancestral homelands and the legal rights of a state. If the study of nations is artificially restricted to this later modern period, then it also limits potential avenues of research into the behaviors of peoples and states in prior eras back to the ancient world.

It is useful to briefly examine some of the major theories that have been developed in the study of nations and nationalism. Amongst the major paradigms created by political scientists and historians to describe the formation and development of nations are primordialism, perennialism, ethno-symbolism and modernism.

According to the modernists, nationalism and nation are the key characteristics of modernity. Modernists believe nations are a recently constructed phenomenon, mostly appearing during and after the Enlightenment period of the 18th century. To this modernists add that nationalism and the construction of nation requires printing presses, capitalism, the modern bureaucratic state and mass literacy, which they believe is the only way nationalist ideology can spread throughout the all levels of society. ${ }^{2}$ Nationalism is related to the rise of the nation-state, while the nations are the result of modernization. ${ }^{3}$

Primordialists recognize the nation or the ethnic identities as a unity of people associated with the periods of ancient history. ${ }^{4}$ The original primordialists of the 19th and early 2oth centuries believed nations had always existed as an intrinsic, natural phenomenon down through the earliest human groupings, even prior to the development of agriculture. ${ }^{5}$ Besides cultural, linguistic, religious, territorial characteristics these political communities distinguish such category as citizenship as well. Under that very large umbrella, many societies could be classified as a nation. However, there was a second wave of the primordialist dis-

\footnotetext{
${ }^{1}$ Leoussi and Grosby 2007, 1.

${ }^{2}$ Anderson 1991, 33-34.

${ }^{3}$ Smith 2009, 6.

${ }^{4}$ Smith 2009, 8.

${ }^{5}$ Smith 2008, 4-5.
} 
course that more clearly defined "natural phenomenon" as common cultural ties of "kinship, custom, religion and language" amongst a group. ${ }^{6}$ Modern academics, such as Steven Grosby believe these cultural traits underpin certain societies, and when a society possesses these traits in addition to a "historic" home territory, that group can constitute a nation regardless historical era. ${ }^{7}$

The perennialists believe that the nations are eternal, nations have existed for a very long time, back to the ancient or medieval periods - the ancient Egyptians, the Greeks, and the Persians were "nations", but they were not a "race". The second school of perennialist thought agrees with this and believes that nations are cyclical rather than permanent and "continually emerge and dissolve, flourish and disappear, in every period and continent". ${ }^{9}$

The philosophy of ethno-symbolism, developed entirely by sociologist Anthony Smith, has a much more open definition of nation than the modernist school. Smith argues there are several historic examples that undermine the "theoretical basis" of the modernist viewpoint and prove there are ancient nations. ${ }^{10}$ His construct suggests that "cultural elements of myth, symbol, memory, value and tradition" are the underlying building blocks of nation, which contrasts with modernisms very specific criteria and allows for the existence of pre-modern nations." To this underlying criteria, Smith argues a nation must possess a historic homeland ${ }^{12}$, real or imagined via myth, have common rights and duties for all members, a distinctive public culture, shared myths of origin and self-definition. He clarifies this point further, indicating an ethnic group does not constitute a nation by default, but that a core ethnic group is often the original creator of a nation and created its shared myths, symbols and values. A. Smith has suggested theorists define key terms such as "nation" and "nationalism" beyond the theoretical limitation of both modernism and primordialism. In his opinion, the problem of modernism is mainly that modernists define the nation as a "modern nation" with characters of European nations of the 18th and 19th centuries, making their definition Eurocentric and partial. ${ }^{13}$ Instead, he proposes an ideal-typical definition of the nation: "a named human population sharing a historic territory, common myths and historical memories, a mass, public culture, a common economy and common legal

\footnotetext{
${ }^{6}$ Smith 2008, 6-7.

${ }^{7}$ Cf. Smith 2008, 7 .

${ }^{8}$ Smith 2009, 3 .

${ }^{9}$ Hutchison and Smith 2000, xxviii.

${ }^{10}$ Smith 2008, 24.

${ }^{11} H u t c h i s o n$ and Smith 2000, xxxv.

${ }^{12}$ Smith 2009, 13-14.

${ }^{13}$ Smith 2005, 95 .
} 
rights and duties for all members". The inclusion of "common rights and duties" in the definition seems to refer to citizenship rights. ${ }^{14}$ Anthony Smith's theoretical perceptions and approaches (in Ethno-symbolism and Nationalism, Cultural Approach) are valuable in the study of nation, ethnos, nationalism in Carthaginian discourse.

"If nation-states are widely conceded to be 'new' and 'historical,' the nations to which they give political expression always loom out of an immemorial past, and, still more important, glide into a limitless future". ${ }^{15}$ The modern concepts such as citizenship and state are identical to the original concept that emerged in Roman society. These concepts derived from the Latin term, civitas (society, city), are civis, (citizen, citizenship), civillis, civilitas (civic engagement, governance, civilized). This paper explores the sociopolitical and state dynamics of the Carthaginian statehood, early manifestations of nationhood and nationalism and also unpacks issues such as the identity and regional ethnicity in Carthaginian discourse. Such issues as identity and state citizenship will be discussed in relation to the Carthaginian model. In this way, the research will be focused on the reconstructive analysis of Carthaginian regional ethnicity and nationality. The research approaches are outlined in the given formulation:

1. to study Carthaginian regional and international extensions, outlining selfascription, self-definition, self-identification and self-significance;

2. to study and determine the assessment of Carthage by other then contemporary societies at the local, regional and transregional levels. A system of both positive and negative evaluations should be considered, evaluating their merits and cultural achievements;

3. to identify and determine the "icon", image or model of Carthage, how this image was preserved in the memory of later societies and modernity in general, how the image remained in later historical memory, and what impact this citystate has on modern historical knowledge: the impact of cultural traditions on historical understanding.

\section{The "Icon" of Carthage, Perception and Evaluation by Modern Historiography}

The British historian Howard Hayes Scullard formed his own opinion about the Punic Wars between Rome and Carthage, and proposed political prediction and imaginable consequences of this conflict: "If Carthage had in fact succeeded in conquering Rome, the history of Western Europe would certainly have taken a very

\footnotetext{
${ }^{14}$ Conversi 2007, 23.

${ }^{15}$ Anderson 1991, 10.
} 
different turn..."16 This viewpoint refers to the Carthaginian Empire of the 4th-5th centuries BC, when the territorial state had already been molded, extending beyond Northern Africa, and started to expand influence on the transregional geographical space, the Atlantic Ocean and the Mediterranean Sea.

The emblematicity of Carthage is evidenced by the reminiscence of recent history when Nazi Germany recalled the Carthaginian Empire. J. Hell discusses regarding Nazi Germany and Carthage ${ }^{17}$ and relies on the French historian, Jules Michelet's opinion $^{18}$ that the state of Carthage was a symbol of the Semitic race which symbolized labor, commerce and sailing, while Rome embodied heroism and legality. According to Michelet, Carthaginians were an "unclean race" and "tyranny of merchants". The conflict between these two empires for European domination was an inevitable historical reality. It was a symbolic conflict between the two states which was repeated later when Nazi Germany confronted the Semites. In order to introduce anti-Semitism, a new political national ideology, it was necessary to return and recall the past, revise and reconsider it. Popular public lectures by the Nazi historian Helmut Berve served to create and propagate the fascist ideology. His public lecture entitled "Rome and Carthage" called for a "devastating war" against the Semites. Just as Rome destroyed Carthage, the nest of the Semites in ancient time, so the modern Semites, who opposed Germany and the Aryan race, must have been eliminated. The Germans had to stop the Semitism of Europe and then take the position of the world-dominant nation. ${ }^{19}$ Alongside the fascist attempt to downplay Carthage, Carthage had become a source of inspiration for many European artists and writers. ${ }^{20}$ In 20o6, the British cinematographer Edward Bazalgette made the heroic-dramatic film Hannibal describing the attack of the famous Carthaginian commander and his army against Rome and her citizens. 40,00o soldiers and 37 elephants set off and crossed 1,500 miles to strike at the enemy, the Romans, on their own land. After crossing the Alps, the Carthaginian won three major battles against Rome at Trebia, Lake Trasimene and Cannae from 218 BC to 216 BC, each successively more devastating than the last. After just three major battles, Rome and her allies had lost approximately 100,000 soldiers and well over 100 magistrates including

\footnotetext{
${ }^{16}$ Scullard 1955, 98-107.

${ }^{17}$ Hell 2010.

${ }^{18}$ Hell, 2010, 175 .

${ }^{19}$ Hell, 2010, 176 .

${ }^{20}$ A historical novel by Gustave Flaubert Salambo (name of the port of Carthage), English playwright Christopher Marlowe's Didona - Queen of Carthage, magnificent paintings by Joseph Turner Dido Building Carthage and Thomas Cole - Curse of the Empire, etc., served to immortalize Carthage in arts and literature.
} 
quaestors, tribunes, and at least eighty senators ( $L i v .22 .49)$. The modern cinematic version of history (although this version is a partial interpretation of Roman and Greek authors' work, e.g. the ancient authors Livius and Polybius recount many stories about the Punic Wars and Carthaginian general Hannibal Barca) has buried the myth created by European Fascist Historians regarding the Carthaginians, that they were just mercantile people and they could not do decent actions on the battlefield. Even earlier the view of Berve that the pure Aryan nation would annihilate the Semites, was invalidated, in 1948, the statehood of Israel was restored. In addition to this, Americans praised the emblematic icon of Carthage and have almost 10 states (e.g. Dakota, Texas, Kentucky, North Carolina, etc.) with cities named after Carthage.

A major new study of the ancient roots of nationalism and its enduring power in the modern world discussed in The Endurance of Nationalism: Ancient Roots and Modern Dilemmas by Aviel Roshwald. According to Aviel Roshwald's opinion nationalism did not emerge in the 19th century ${ }^{21}$ as a by-product of the modernization and print capitalism. ${ }^{22}$ Unlike writers who see nationalism strictly as a modern phenomenon, Roshwald begins by examining nationalism in antiquity to support his assertion that national identification has a long legacy in human history. Roshwald directly challenges prevalent scholarly orthodoxies about the exclusively modern character of nationalism. He argues that nationalism's enduring power to shape the world we live in arises directly out of its position at the heart of inescapable social and political paradoxes that are not only fundamental to the modern experience, but many of whose roots can be traced back into ancient history. Modern nationalisms, the author contends, cannot be fully understood without first examining their ancient counterparts and archetypes. Nationalism has ancient origins, articulations of nationalism are formed in the Ancient World, and these foundations generate contemporary manifestations. In citing a range of examples across time and cultures, Roshwald pays particular attention to ancient Jewish and Greek polities examining enduring themes used to create the idea of a

${ }^{21}$ Roshwald 2006, 349 .

${ }^{22}$ Booker 2009, 89-91. Print capitalism is a theory underlying the concept of a nation, as a group that forms an imagined community, that emerges with a common language and discourse that is generated from the use of the printing press, proliferated by a capitalist marketplace. Capitalist entrepreneurs printed their books and media in the vernacular (instead of exclusive script languages, such as Latin) in order to maximize circulation. As a result, readers speaking various local dialects became able to understand each other, and a common discourse emerged. Benedict Anderson (1991, 224) argued that the first European nation-states were thus formed around their "national printlanguages". 
"nation." There are far more resources in the case of modeling both state models than we would find in the case of Carthage. We have to admit that we operate with the limited primary sources regarding Carthaginian self-ascription, selfesteem or self-identification, which is abundant in the case of the Hebrews and Greeks.

\section{Carthage in the Memory of Neighboring Peoples}

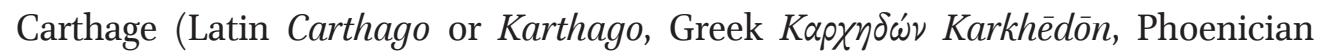
Qart-hadašt, "new city") was founded in the first half on the 8th century BC (814/13 BC). It was a high urban center in North Africa and the Mediterranean. According to Greek and Roman tradition, the city was founded by Tyrian queen Didona / Dido (Hornblower and Spawforth 2003, 467). Exiled by her own brother Pygmalion, she fled from Tyre to Africa, bought land from a local chief, and founded a city (Appian VIII, pt. 1, The Punic Wars I., 1.). Insisting on the chief's forced marriage, the woman responded with extreme action, burning herself on the sacred bonfire (Timaeus, FGrH i.197). In the patriarchal Greco-Roman world, cities were founded only by men. As far as I know, she is the only mythical heroine who is credited with founding a city. Virgil tells the story of Dido in The Aeneid differently: Dido was a contemporary of Trojan hero Aeneas; the woman fell in love with Aeneas who had fled from Troy to Carthage. When Aeneas had left Carthage and moved to Italy, Dido tragically ended her life. Modern scholars equated Didona / Dido with the patron goddess of Carthage Tanit and her symbols. ${ }^{23}$ Tyrian colonizers brought the cult of goddess to North Africa. ${ }^{24}$ Together with the political influences of the Carthaginians, the cult spread to the islands of Malta and Ibiza.

Carthage, a powerful Mediterranean state, is deeply etched in the memory of its neighboring states and peoples. The majority of these states and their citizens were enemies and rivals of Carthage. If we make a list of Carthaginian enemies, Rome will definitely be at the top. Most of the Greek city-states were also rivals of the Carthaginians and, consequently, Greek authors occupy an honorable place in the description of the history of the Carthaginians. At the same time the most important and abundant references are attributed to Roman-Greek authors, some of which reflect objective reality, some of which are very biased, and some of which are more hostile. I will have to study the statehood of Carthage and its citizens mainly with the help of these sources and suggest my own reinterpretation.

\footnotetext{
${ }^{23}$ Cross 1973; Aubet 2001,343.

${ }^{24}$ Pritchard 1982,82).
} 


\section{The Statehood of Carthage and its Citizens: \\ Change of Identity-Defining Terms, Replacement and \\ Establishment of New Nominals}

Phoenician city-states began commercial expansion; the colonists torn from the city of Tyre began to settle in the "new city" - Carthage. In early Greek sources, the Carthaginian population is identified with the Phoenicians. The Phoenicians called themselves Chna/ $\chi$ v $\alpha$ which means "lower land" and corresponds to "Canaan" (indication of a correlation of ethnicity with geographical-territorial space). In Amarna correspondence this region (Phoenicia-Canaan) is referred to

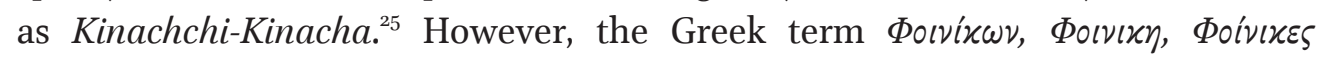
(Phoenicia, Phoenicians) refers to the entire Semitic population, the original communities of the Levantine coastline in the period 1200 to 333 BC. ${ }^{26}$ The Greek

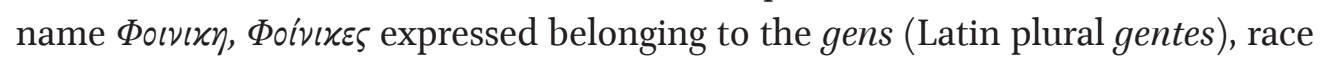
and territory. ${ }^{27}$ It should also be noted that the relationship between Tyre and Carthage was not always benevolent. For example, when Tyre was besieged by Alexander the Great in 333 BC, the city asked for help from Carthage but Carthage did not support Tyrians. Although Carthage had plenty of time, Tyre was besieged for almost seven months. The cooling of relations is felt even earlier, in a period of Persian domination when Tyre was under Persian rule in the 6th century BC. Under the Magonids, the Carthaginian Empire expanded to include Sardinia, Libya, and for almost a decade much of Sicily but did not interfere in the Persian-Tyrian conflict. Despite their political neutrality, the Carthaginians sent gifts to the sacred temples of Tyre. ${ }^{28}$

The Latin terms-Poenus, Poeni indicated a sort of ethnicity and race (similar to Hellen) and these terms emerge in relation to the diasporas formed in the western Mediterranean space. The terms, Poenus, Poeni, are related to the period of Carthaginian political hegemony and glory (in the mid-sixth century BC) ${ }^{29}$ By this time Carthage was already formed as a naval empire, and in the perception of neighboring states it was an "other", a new state unity, different from the earlier period. The new political state connected with a new ethnic denomination, and Фoivoxes (the Phoenicians) was replaced by the new Latin term-Poenus.

Ethnic identity or nationality is not always a "naturally" established fact of life and is not limited to the field of genetic inheritance. The formation of nationality

\footnotetext{
${ }^{25}$ Davies 2012, 78.

${ }^{26}$ Garbini, 1994, 74-6; Prag 20o6, 4.

${ }^{27}$ Davies 2012, 78.

${ }^{28}$ Elayi 1981, 15-29.

${ }^{29}$ Prag 2010, 51-71, note 1.
} 
involves the various channels and processes in the discourse. Because we do not know what the Carthaginians called themselves, or how they expressed their identity, there is a great temptation to presume that they recognized the new political and national denominations used by the Greco-Romans. These new nominals-Poenus/Poeni and other term-karchedonios (Carthaginians) define processes related to Punic oikoumenē. The process of turning Carthage into an empire was followed by a change of identity-defining terms and the establishment of new designations. Poeni, by "nationality," could have been Carthaginian citizens as well. ${ }^{30}$ However at the same time, just Poeni did not necessarily mean Carthaginian citizenship. ${ }^{31} \mathrm{~A}$ remarkable point is that term "Carthaginian" is a political marker/designator and emphasizes the citizen's relationship to the state (Palmer 1997, 74, note 7). A similar example can be brought from the Greek world; "Athenian" ${ }^{32}$ is the same political marker as "Carthaginian", while "Hellenes" ("E $\lambda \lambda \eta \nu \varepsilon \varsigma)$ - has ethnic-national correlation. "Hellenes" are those who develop into a larger nation, shared a common ethnicity, language, gods and customs across the peninsula regardless of their poleis' borders, and can live anywhere, even in the Greek cities of Asia Minor. ${ }^{33}$ It is especially noteworthy that the new term Poeni, is not only stands for ethnic or national identity, but also implies a negative stereotype about these people. This propaganda was carried out by Latin-Greek historiography. The tyrants of the Greek city-states often opposed the Carthaginians for the sphere of influence, and consequently, the Greeks established negative rhetorical expressions. Rome involved in international confrontation quickly embracing the Greek Anti-Punic campaign, turning rhetoric into an ideology. ${ }^{34}$ At the same time, the sources make it clear that Carthaginiensis had become a clearly established political identity by the 6th century BC. The attitudes of Roman-Greek authors are also poling apart in the case of the karchedonios and Poeni. The Poeni in Latin sources almost always had a negative connotation, while the Carthaginians get a relatively better estimate. ${ }^{35}$

The scarcity of epigraphic material from Carthage poses a serious obstacle to the interpretation of these terms. At least one epigraphic inscription at our dis-

\footnotetext{
${ }^{30}$ Prag 2006, 6.

${ }^{31}$ Prag 2010, 51, note 1.

${ }^{32}$ Athens, for example, was an amalgamation of cities from the surrounding the Attic region and contained all the requirements for a nation. Its people shared a common language, common rights and myth-history. It also had an elected government and national borders.

${ }^{33}$ Prag 2006, 7.

${ }^{34}$ Davies 2012, 79 .

${ }^{35}$ Brizzi 2011, 483-498; Prag 2006, 1-37; Dubuisson 1983, 159-167.
} 
posal offers important material for interpretations. Epigraphic text, the so-called tessera hospitalis ${ }^{36}$ found in Carthage, near the necropolis, close to the Church of St. Monica which dates back to the second half of the $5^{\text {th }}$ BC. ${ }^{37}$ The inscription is in the Etruscan language and it is only one small sentence - mi puinel karvazie. Different authors offer various versions of translations, for example I. Shifman

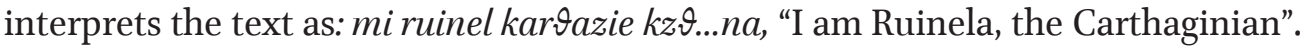
Instead of "puinel” he reads "ruinel," because the „p" sign has „r" meaning in the Etruscan language..$^{38}$ According to Shifman, this inscription belongs to an Etruscan person (named Ruinela) who calls himself a "Carthaginian” and presumably acquired Carthaginian citizenship. ${ }^{39}$ Shifman pays special attention to the word kardaz / karӨazie and admits the fact that this version is used by Roman authors as well. Macintosh Turfa, relying on E. Benveniste ${ }^{40}$ and on M. Pallottino, ${ }^{41}$ interprets the text as "I belong to Puina of Carthage". ${ }^{42}$ According to Macintosh Turfa an ivory plaque with inscription belonged to Etruscan metics, resident merchants, in the city. Jonathan Prag's interpretation and reconstruction is recent and looks much more convincing to me. ${ }^{43}$ Prag relies on Peruzzi's ${ }^{44}$ interpretation and links puinel to Latin poenulus that is a form use by Cicero (Postea tuus ille Poenulus - scis enim Citieos, clientes tuos, e Phoenica profectos, De Finibus 4.56). A suffix ulus denoted ethnicity in Latin. ${ }^{45}$ Thus, this sentence is interpreted as: "I (am) Puinel (or Punic) from Carthage." The both versions, Poenulus and Puinel can be taken as denoting ethnic or national identity. Interesting also to consider this "double" designation of origin in this epigraphic inscription - "puinel" and "from Carthage". In my opinion, these designators allow us to trace global processes when Carthage became a transregional empire and the ethnic and political relationships of communities were divergent in relation to it. A logical question arises regarding the above-mentioned inscription: If the owner of the epigraphic inscription is an ethnic descendant of the Semitic Phoenician, then why does he write the text in Etruscan in Carthage? And if he is Etruscan, then he admits that his ethnicity has changed, he considers himself a puinel and at the

\footnotetext{
${ }^{36}$ CLE: Carmina Latina Epigraphica $555^{2}$.

${ }^{37}$ Prag 20о6, 8; Шифман 1963, 140; Turfa 1986, 78.

${ }^{38}$ Шифман 1963, 140; Benveniste 1933, 245-249).

${ }^{39}$ Шифман 1963, 140.

${ }^{40}$ Benveniste 1933, 245-49.

${ }^{41}$ Pallottino 1964, 117.

${ }^{42}$ Turfa 1986, 78 .

${ }^{43}$ Prag, 2006, 8.

${ }^{44}$ Peruzzi 1970, 1, 2 O.

${ }^{45}$ Skutsch 1968, 143-4.
} 
same time has acquired the citizenship of Carthage. ${ }^{46}$ From a modern theoretical perspective these processes can be interpreted, and in some way we can draw analogies with the Greek model. "Dual ethnicity "appears from the $5^{\text {th }}$ century $\mathrm{BC}$, the first is "state-associated ethnicity" and the second one is "regional ethnicity" (in case of the Greek model cf. Hansen). ${ }^{47}$ Morgan Hansen's typology of ethnicity related to the Greek state model, but it can be extended and applied to Carthage and Punes as well. The first community, the so-called "state-associated ethnicity," were citizens of the Carthaginian state. Naturally they also were the Poeni. The second community may be the Poeni who were not citizens of the state, though had experienced the cultural-political effect of "Punicization" (here we can recall the same process of Romanization, or the process of Hellenization). Thus, the first group unites people on political grounds and, possibly, allows foreigners to get Carthaginian citizenship. The second group can be distinguished as regional ethnicity, when a certain group does not have Carthaginian citizenship, but is politically and culturally affiliated with Carthage. In the language of modern political terminology "I (am) Puinel (or Punic) from Carthage" means "Carthaginian Puns". It is a national identity within an established political community, that is, citizenship.

The Carthaginian Republic ${ }^{48}$ did not foster the same type of unity as Rome shared with its allies. In contrast to Rome, Carthage operated more like an ethnic nation in the model of the city-state. Their model for handling neighbors could include handing out citizenship rights of any kind on certain occasions, though they made alliances with neighboring states that were in turn maintained via monetary rewards or the threat of violence. Carthage also forced some regions and cities to be Carthaginian client states and ruled over them with an iron fist. This led Hannibal's army, and most Carthaginian armies for that matter, to be composed of mercenaries with little stake in Carthaginian society or government. It is known that the Carthaginians controlled the conquered territories with a system of paying tribute, the territory was divided into administrative units and taxed. Moreover, Carthage's empire consisted of an often nebulous network of Punic colonies, subject peoples, client states, and allied tribes and kingdoms ${ }^{49}$; one can assume that these individuals from these different realms and nationalities formed a particular social or political class in relation to the Carthaginian

${ }^{46}$ This reality points to global migration and gives rise to an impression of the beginning of the formation of a nation. In many ways it resembles to the process of how the Jews left Egypt (not yet a nation) and how other peoples joined them their way to Canaan.

${ }^{47}$ Hansen 1996, 174-5.

${ }^{48}$ The oligarchic republic after $483 \mathrm{BC}$.

${ }^{49}$ Hoyos 2003, 20-22. 
government and they were called Poeni. Carthaginian Citizenship was defined by inheritance and the line of honor (Greek proxeny). ${ }^{5}$ Presumably, there were other variants of the affiliation agreement with the state of Carthage according to Cicero (cf. Cicero, Pro Balbo 5.30.39) when in 206 the people of Gades made a treaty with Rome, they deliberately distanced themselves from the other Poeni. Gades employed a Punic constitution (iura Poenorum), and at the end of the 6os Caesar had expunged "a particular ingrained barbarity from the customs and institutions of the people of Gades" . ${ }^{11}$ According to this source, it is clear that the population outside Carthage, in the transregional system (Gades, Sardinia and North Africa, the provinces occupied by Carthage), to some extent experienced the cultural-political effect of Carthaganization. At a time when Carthage no longer existed and the population remained, some part of this population "did not forget" its "nationality" or "transregional nationality". A funerary epitaph from near the start of Via Latina, dating from the very end of the Republic 48BC reads: "... Erotis, of the Punic nation, has been buried". This inscription constitutes the only known instance of an individual self-definition, self-identification by the label Poenus in Republican period. ${ }^{2}$

\section{Conclusion}

The issues of the identity of the individuals arose after the emergence of the first cities and city-states. With the emergence of territorial-political statehood, the idea of identity becomes more complex and includes various manifestations: on the one hand, ethnic-cultural (to some extent, religious as well) and political on the other.

The establishment of new political and ethnic labels, the transition to identitydefining terms and their replacement with new ones, the clarification of their relations with statehood are not one-time acts prescribed by a universal instruction. ${ }^{53}$ Consequently, new conceptual visions in different periods of history lead to the establishment of new concepts. Nationalism, nation, state are modern concepts but their archetypes date back to the period of ancient history. The material in relation to Carthage and the modern interpretations of ancient concepts make me believe that these terms are related and represent indicators of the ethnicpolitical interrelationship of individuals (or groups) and are a kind of signal to their national identity. Many factors may be behind this identity, such as ethnici-

\footnotetext{
${ }^{50}$ Manfredi 2003; Prag 2006.

${ }^{51}$ Prag 2006, 13 .

$5^{2}$ di Stefano Manzella 1972, 123; Prag 2006, 29.

${ }^{53}$ The Latin term Natio or the Greek Politeia are originally ambivalent concepts and can hold different meanings (cf. Lewis and Short 1956).
} 
ty and common roots, economic relations and community, political subordination and shared legal norms of governance, cultural synthesis, ethnic assimilation, etc., but I will refer to these macro-processes in one concept as culturalpolitical effect of Punicization where Carthage was the metropolis.

\section{REFERENCES}

Anderson, B. (1991) Imagined Communities Reflections on the Origin and Spread of Nationalism. London.

Benveniste, E. (1933) «La tablette d'ivoire de Carthage», SE. Studi Etruschi VII, 245-249.

Booker Jr., R. M. (2009) "The Endurance of Nationalism: Ancient Roots and Modern Dilemmas (review)," Journal of Jewish Identities 2.1, 89-91.

Brizzi, G. (2011) "Carthage and Hannibal in Greek and Roman Memory." In I D. Hoyos (ed.). A Companion to the Punic Wars. Wiley-Blackwell, 483-498.

CLE - Carmina Latina Epigraphica 5552.

Conversi, D. (2007) "Mapping the Field: Theories of Nationalism and the Ethnosymbolic Approach," in Nationalism and Ethnosymbolism: History, Culture and Ethnicity in the Formation of Nations, edited by A. S. Leoussi and S. Grosby. Edinburgh: University Press, 15-31.

Davies, H. (2012) Rome, International Power Relations, and 146 BCE. Dissertation for the Degree of Doctor of Philosophy. The University of Texas at Austin.

Di Stefano Manzella, I. (1972) "Un'iscrizione Sepolcrale Romana datata con la seconda Dittatura di Cesare," Epigraphica 34, 105-30.

Hornblower, S. and A. Spawforth, eds. (2003) The Oxford Classical Dictionary. Oxford University Press, 467.

Dubuisson, M. (1983) "L'image du Carthaginois dans la littérature latine," in E. Gubel, E. Lipinski, and B. Servais-Soyez, eds. Studia Phoenicia 1-2. Louvain: Peeters, 159-167.

Elayi, J. (1981) "The Relations between Tyre and Carthage during the Persian Period," Journal of the Ancient Near Eastern Society 12, 15-29.

FGrH - Jacoby, F. ed. (1923-55) Fragmente der Griechischen Historiker. Berlin.

G. Garbini, (1996) "Fenici e Cartaginesi nel Tirreno," in AttiConv Magna Grecia, Etruschi, Fenici. Taranto, Istituto per la Storia e l' Archeologia dell Magna Grecia. Napoli, 73-85.

Hansen, M. H. (1996) "City-ethnics as evidence for the Polis identity," in M. Hansen, and K. Raaflaub. More Studies in Ancient Greek Polis. Stuttgart, 169-96.

Hell, J. (2010) "Imperial Ruin Gazers, or Why did Scipio Weep," in Ruins of Modernity, eds. Julia Hell and Andreas Schönle. Duke University Press, 169-193.

Hoyos, D. (2003) Hannibal's dynasty. Power and Politics in the Western Mediterranean, 247-183 BC. London.

Hutchinson, J. and Smith, A. (2000) Introduction to Nationalism: Critical Concepts in Political Science, New York: Routledge.

Macintosh Turfa, J. (1986) "International Contacts: Commerce, Trade and Foreign Affairs," in Etruscan Life and Afterlife. Wayne State University, Detroit. 
Manfredi, L.I. (2003) La Politica Amministrativa di Cartagine in Africa. Roma: Atti della Academia Nazionale dei Lincei.

Pallottino, M. (1964) "Scavi nel santuario etrusco di Pyrgi, Le iscrizioni etrusche," Archeologia Classica 16. 49-117.

Palmer, R.E. (1997) Rome and Carthage at Peace. Historia Einzelschriften 11, Stuttgart.

Peruzzi, E. (1970) Origini di Roma, 2 vols. Firenzia.

Prag, J. (2006) "Poenus plane est - But who were the "Punickes"? in Papers of the British School of Rome, v. LXXIV. London.

Prag, J. (2010) "Tyrannizing Sicily: the despots who cried 'Carthage'," in A. Turner, K.O. Chong-Gossard and F. Vervaet, eds. Private and Public Lies: The Discourse of Despotism and Deceit in the Graeco-Roman World. Leiden: Brill, 51-71.

Roshwald. A. (2006) The Endurance of Nationalism: Ancient Roots and Modern Dilemmas. Cambridge University Press.

Scullard, H.H. (1955) "Carthage," Greece and Rome, second series, vol. 2. Cambridge University Press, 98-107.

Shifman, I.Sh (1963) Vozniknovenie Karfagenskoj derzhavy [Шифман, И.Ш. (1963) Возникновение Карфагенской державы. Москва-Ленинград.] Moskva-Leningrag (in Russian).

Skutsch, O. (1968) "Volsculus," in Skutsch, O. Studia Enniana. London, 143-4.

Smith, A.D. (2005) "The Genealogy of Nations: An Ethno-Symbolic Approach," in When is the Nation? Towards an Understanding of Theories of Nationalism, edited by A. Ichijo and G. Uzelac. Routledge, 94-113.

Smith, A.D. (2008) The Antiquity of Nations. Malden, MA: Polity Press.

Smith, A.D. (2009) Ethno-symbolism and Nationalism: A Cultural Approach. Routledge. 